\title{
喘息の治療と管理におけるサルメテロール/フルチカゾン製剤の費用対効果
} 一プロピオン酸フルチカゾンとの比較検討一

\author{
東田有智, ${ }^{a, e}$ 西間三馨, $b, e$ 荒川一郎, ${ }^{*, c}$ 白神 $\quad$ 誠, ${ }^{c}$ 宮本昭正 ${ }^{d, e}$
}

\section{Cost-effectiveness of Salmeterol/Fluticasone Combination Therapy vs. Fluticasone Propionate in Japanese Asthmatic Patients}

\author{
Yuji ToHDA,,$^{a, e}$ Sankei Nishima, ${ }^{b, e}$ Ichiro ARAKAWA, ${ }^{*, c}$ \\ Makoto SHIRAGAMI, ${ }^{c}$ and Terumasa MIYAMOTO ${ }^{d, e}$ \\ ${ }^{a}$ Department of Respiratory and Allergology, Kinki University, School of Medicine, 377-2 Ohno-Higashi, \\ Osakasayama, Osaka 589-8511, Japan, ${ }^{b}$ National Hospital Organization, Fukuoka National Hospital, \\ 4-39-1 Yakatabaru, Minami-ku, Fukuoka 811-1394, Japan, ' ${ }^{\circ}$ Unit of Social and Administrative \\ Pharmacy Sciences, College of Pharmacy, Nihon University, 7-7-1 Narashino-dai, Funabashi, \\ Chiba 274-8555, Japan, 'Japan Clinical Allergy Research Institute, New Shimbashi Bldg 318, \\ 2-16-1 Shimbashi, Minato-ku, Tokyo 105-0004, Japan, and ${ }^{e} N P O$ Japan Asthma and \\ COPD Forum (JASCOM), c/o PRAP Japan Inc., Kasuya Bldg, 2-9 \\ Sakuragaoka-cho, Shibuya-ku, Tokyo 150-0031, Japan
}

(Received April 25, 2009; Accepted November 29, 2009)

\begin{abstract}
We commenced to estimate the economic impact of salmeterol/fluticasone combination (SFC) therapy compared to fluticasone propionate (FP) therapy for asthma control in Japanese patients. A Markov model with five health states, developed by Price in 2002, was used. 1-week transition probabilities among status of asthma management were obtained from literature and epidemiological data from public data base. Direct cost for treatment was estimated from Japan medical fee schedule. Cost and effectiveness were not discounted due to 12 -week simulation by the model. Univariate sensitivity analyses were undertaken to examine the main variables affecting cost-effectiveness. Probabilistic analysis was also undertaken to discuss statistical argument and to provide information for decision-making. In this analysis, the model was run over a 12 -week period of time using transition probabilities. The results showed that treatment with SFC resulted in a higher proportion of totally controlled weeks per patient than treatment with FP (65.0 vs. $49.5 \%$; incremental effectiveness by $15.5 \%$ ), and lower mean direct asthma management costs (¥168 702 vs. ¥227 820). Probabilistic sensitivity analysis, conducted to assess robustness of the above base case result, showed that in the $95 \%$ of cases SFC was dominant (more effective and less costly) to FP. It suggested that SFC will be the most cost-effective therapy for asthma control. It would, however, be required to further evaluate cost-effectiveness of SFC in long-term observation.
\end{abstract}

Key words_asthma; economics; salmeterol/fluticasone; fluticasone propionate; total control

\section{緒 \\ $\overline{\overline{\overline{\bar{D}}}}$ \\ 吸入ステロイド薬（ICS）であるフルチカゾンプ ロピオン酸エステル（FP） と長時間作用性 $\beta_{2}$ 刺激 薬（LABA）であるサルメテロールキシナホ酸塩} （SLM）の配合剂（salmetrol/fluticasone combina-

$a$ 近畿大学医学部呼吸器・アレルギー内科, $b$ 国立病院 機構福岡病院, ${ }^{c}$ 日本大学薬学部薬事管理学ユニット, ${ }^{d}$ 日本臨床アレルギー研究所, ${ }^{e} \mathrm{NPO}$ 法人 Japan Asthma and COPD Forum (JASCOM)

*e-mail: uhi09701@ nifty.com
tion；SFC）が，本邦においても成人気管支喘息治 療の場で使用できるようになった。 SFC は単に気 道炎症を抑える ICS と気管支を長時間拡張させる LABA それぞれ単独の相加作用だけではなく，FP と SLM はFP の抗炎症作用の増強や $\beta_{2}$ 受容体, G タンパク合成の増加という相乗作用を示す。その結 果, SLM と FP を併用することによって ICS を増 量するよりも呼吸機能, 喘息症状あるいは気道炎症 や気道リモデリングに対する改善効果が更に高くな るというユニークな臨床効果を有する. ${ }^{1-3)}$ しかも, FP 及び SLM を別々に吸入するより, SFC 1 剂で 
吸入することにより FP 及び SLM が同一部位に到 達する確率が高くなり，相乗作用がより高まること が示唆されている. ${ }^{4)}$ SFC はまた，ICS にロイコト リエン受容体拮抗薬（LTRA）やテオフィリン徐放 製剂を併用した場合に比べ，呼吸機能や喘息コント ロールなど臨床症状改善効果が高いことが報告され ている.5,6) さらに SFC 1 剂による治療は ICS 単剤 若しくは ICS に他剂を併用する治療よりもアドヒ アランスの向上が期待でき, ${ }^{7)} \mathrm{SFC}$ による喘息コン トロールのメリットは患者にとって大きいと考えら れる，日本アレルギー学会の「アレルギー疾患診 断・治療ガイドライン $2007(J G L 2007) 1^{8)}$ では，軽 症持続型から SFC の使用が記載され，また国際 ガイドラインである Global Initiative for Asthma (GINA) ${ }^{9)}$ では 6 歳以上の喘息患者の第一選択薬 （治療ステップ 3 以上）として，米国のガイドライ ン (Expert Panel Report 3; EPR3) ${ }^{10)}$ では, 低用量 ICS のみでは不十分な 5 歳以上の喘息患者（ステッ プ 3 以上）に対して推奨されている.

近年 EBM (evidence-based medicine) という概念 が重要視される中, 臨床効果だけではなく,「メ夕 分析」，「決断分析」，「費用効果分析」という統合型 研究 ${ }^{11)}$ による同剤の評価は，患者個人に対してどの ような治療を行うか臨床の場での意思決定には欠か せない要素である。しかし，国内では同剂に関する 日本独自の情報を統合した EBM の情報は十分とは 言えず，特に費用効果分析による評価は日本では行 われていない。費用効果分析は，限られた医療資源 の中で医療費だけでなく治療効果も加味し，EBM
の評価を行う手法として有用である。喘息治療のた めにかかった医療費は，厚生労働省の国民医療費 (1995 年から 2004 年の統計) ${ }^{12)}$ によると, 近年微減 傾向にあるものの，年約 4000 から 4500 億円の間を 推移しているとされている。 33 兆円強と言われて いる医療財政に占める割合は少ないものの，喘息は 呼吸器系疾患の中で最も高額な医療費を支出する疾 患の一つとなっている，喘息治療において 4000 億 円の医療費支出があるという実態を背景に，費用対 効果のバランスを考えた医療資源の適切な配分が求 められる中，同剤が医療財政に与える影響を検討す る必要があると考えた。

今回，われわれは日本における SFC の経済性評 価の一環として，ICS に対する費用効果分析を試み たので報告する.

\section{分 析 方 法}

1. 分析モデルと対象 本分析では, サルメテ ロール／フルチカゾン製剤 $(50 / 100 \mu \mathrm{g}$ 製剤，SFC） の経済評価を行うため，2002 年 Price らが報告 ${ }^{13)} し$ た喘息の治療・管理に関する臨床モデル（通称 Markov model）を使用した（Fig. 1)。このモデル は，喘息の国際的なガイドラインである GINA ガ イドライン9)で示されている喘息の状態を参考に,

“Total control (successfully control13) : 管理成功; TC)", “Well control (sub-optimal control ${ }^{13)}$ : 準管 理成功 ; $\mathrm{WeC})$ ", “Hospital-managed exacerbation : 要入院加療 $(\mathrm{HP})$ ", “Primary care managed exacerbation : 要予定外受診（PC）”, 及び“Treat-
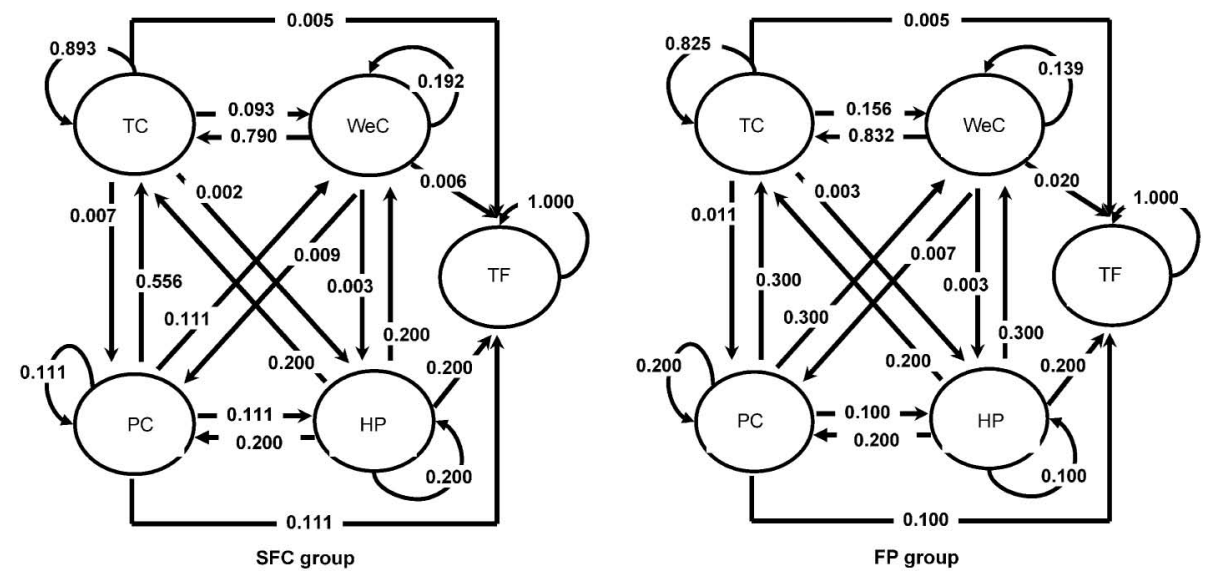

Fig. 1. Markov Model for Treatment and Management of Asthma ${ }^{13)}$ and Transition Probabilities in Each Group

FP; fluticasone propionate, SFC; salmterol/fluticasone combination, TC; total control (represents successfully control), WeC; well control (represents sub-optimal control), HP; hospital-managed exacerbation, PC; primary care managed exacerbation, TF; treatment failure. 
ment failure : 不成功 $(\mathrm{TF})$ " の 5 つの健康状態の 間を 1 週間毎に推移するように設計されている. “Total control” 及び “Well control”の定義は， Table 1 に示す通りである。なお，JGL で重症度分 類の判定をする際，臨床所見が GINA ガイドライ ンの定義と同じであり，“Total control”及び “Well control” の考え方は日本のガイドラインに も取り入れられている。 したがって，Priceらのモ デルは日本における喘息治療薬の経済評価へも応用 が可能である.

このモデルにおける分析の対象は, 15 歳以上で中 等度持続型以上 $($ Step 3, 4) の喘息患者を想定した。

\section{2. 移行確率（transition probability） モデル}

Table 1. Definitions Used to Determine Level of Asthma Control Achieved in a 1-week Period

\begin{tabular}{|c|c|}
\hline & $\begin{array}{l}\text { Well control (represents } \\
\text { sub-optimal control; WeC) }\end{array}$ \\
\hline $\begin{array}{l}\text { ・喘息のために夜間に起きる } \\
\text { ことがな } \\
\text { ・救急外来への受診がない } \\
\text { ・急性増悪がない } \\
\text { ・喘息治療を変更するほどの } \\
\text { 治療関連有害事象がない } \\
\text { さらに, 次のすべての条件に } \\
\text { 該当: } \\
\text { ・症状がない } \\
\text { ・緊急措置としての気管支拡 } \\
\text { 張薬の使用がない } \\
\text { ・早朝 PEFが期待値の } 80 \% \\
\text { 以上 }\end{array}$ & $\begin{array}{l}\text { ・喘息のために夜間に起きる } \\
\text { ことがな } \\
\text { ・救急外来への受診がない } \\
\text { ・急性増悪がない } \\
\text { ・喘息治療を変更するほどの } \\
\text { 治療関連有害事象がない } \\
\text { さらに, 次の中で少なくとも } \\
2 \text { つの条件に該当 : } \\
\text { ・有症状日数が } 2 \text { 日以下, あ } \\
\text { るいは症状スコアが } 1 \text { を超 } \\
\text { えている } \\
\text { ・緊急措置として気管支拡張 } \\
\text { 薬の使用が } 2 \text { 日以, ある } \\
\text { いは } 1 \text { 週間の総使用回数が } \\
8 \text { 吸入以下 (4 回程度) } \\
\text { ・早朝 PEFが期待值の } 80 \% \\
\text { 以上 }\end{array}$ \\
\hline
\end{tabular}

PEF; peak expiratory flow.
に組み込む移行確率を得るために，国内のランダム 化比較試験（RCT）成績を精査した。国内では $\mathrm{SFC}$ の RCT は 2 試験ある. 1 試験は SFC と SLM との比較, ${ }^{14)}$ もう 1 試験は SFC と, FP と徐放性テ オフィリンの併用との比較6)である。前者は本分析 の趣旨と異なるため，対象から除外した，後者は公 表論文と新薬の申請資料概要 ${ }^{14)}$ を閲覧しても，モデ ルに組む込む妥当は変数を入手できなかった.

そのため, Price らの報告に記載されている変数 を使用する検討を行った（Fig. 1)。JGL2007 は， 近年 GINA を踏まえた標準治療を推奨している. Price らの分析の元になった Kavuru ら ${ }^{15)}$ の RCT で は，ICS の投与量が BDP 換算で 250-420 $\mu \mathrm{g} /$ day, SLM $42 \mu \mathrm{g} /$ day と国内の投与量と異ならなかっ た。したがって，Kavuruらの報告に基づいて推定 された Price らの移行確率は，日本向けの分析にも 応用が可能であると考えた。

3. 費用パラメーター（cost parameter） 本分 析では，「主の喘息治療薬（SFC あるいはフルチカ ゾン：FP）費用」, 「併用薬剤費用」,「入院費用」, 「救急外来受診費用」，及び「予定外受診費用」を費 用パラメーターとしてモデルに組み込んだ。また， 各費用パラメーターの設定条件は以下の通りである.

SFC 及び FP の費用は 2007 年の薬価を使用した.

併用薬剂の費用については, SFC の臨床研究で ある FIRST study (6 カ月間観察) 16 ) で報告されて いる 277 名の併用薬使用状況を, 2007 年の薬価で 金銭価値に置き換えた後集計し，6 カ月当たりの平 均費用及び 95\% 信頼区間（confidence interval; CI） を計算した（Table 2)。さらに，それを 1 週間当た りに換算した。

Table 2. Co-medication Costs Input into the Model

\begin{tabular}{l|c|c|c}
\hline \hline & Mean & $95 \%$ lower limit & $95 \%$ upper limit \\
\hline Per 6 months & 46904 & 15135 & 98731 \\
\hline Per a week & 1954 & 631 & 4114 \\
\hline
\end{tabular}

\begin{tabular}{l|l|c|c|c|c|c}
\hline \hline \multicolumn{1}{c|}{ Controllers } & \multicolumn{1}{|c|}{ Name } & Dosage & NHIP & Daily price & Duration & Cost (JPY) \\
\hline Oral theophylline & Teofurmate $400 \mathrm{mg}$ & $400 \mathrm{mg}$, UID & 9.9 & 9.9 & $180 \mathrm{~d}$ & 1782 \\
\hline Systemic $\beta_{2}$ agonist & Cateptin tab $0.05 \mathrm{mg}$ & $50 \mu \mathrm{g}$, UID & 7.2 & 7.2 & $180 \mathrm{~d}$ & 1296 \\
\hline Oral allergic & Ketoten $1 \mathrm{~g}$ & 1 Cap BID & 10.2 & 20.4 & $180 \mathrm{~d}$ & 3672 \\
\hline LTRA & Kipres/Singulair $10 \mathrm{mg}$ & 1 Tab, UID & 306.8 & 306.8 & $180 \mathrm{~d}$ & 55224 \\
\hline
\end{tabular}

LTRA; leukotrien receptor antagonist, NHIP; national health insurance price, UID; once a day, BID; twice a day. 
入院費用については，急性期入院医療における診 断群分類包括評価 Diagnosis Procedure Combination (DPC) の診断群分類点数表 [喘息（15 歳以上） ／手術・処置 2なし（喘息 0401003099x0xx） ）に平 均在院日数（12.5 日間) ${ }^{17)}$ をかけて総点数を計算 し，それを 1 週間当たりの費用に換算した。したが
つて，SFCなどの喘息治療薬の費用はこの中に包 括化されている．なお，医療機関毎に設定されてい る医療機関係数は，計算に含めていない.

救急外来受診費用については，JGL20078）を参考 に喘息の急性増悪（中発作）における初期及び追加 治療レジメンを仮定し，それを診療報酬点数で置き

Table 3. Regimen for Estimate of Emergency Room Visit

\begin{tabular}{|c|c|c|c|c|c|}
\hline Item 1 & Category & Condition & Point & Freq & Total \\
\hline Chap 1 visit fee & Initial visit fee & Once & 270 & 1 & 270 \\
\hline Chap 1 visit fee & Extra fee for visit at night & Visit at 22:00 & 480 & 1 & 480 \\
\hline Chap 1 instruction fee & Drug information & Once a month for outpatients & 10 & 1 & 10 \\
\hline Chap 1 instruction fee & Asthma instruction & Once a month & 25 & 1 & 25 \\
\hline Chap 5 medication & Prescription filled & A medicine for external application (per prescription) & 6 & 1 & 6 \\
\hline Chap 5 medication & Prescription & Per prescription & 42 & 1 & 42 \\
\hline Chap 5 medication & Drug & See Appendix $1^{*}$ & 102 & 1 & 102 \\
\hline Chap 5 medication & Prescription skill & Once a month & 8 & 1 & 8 \\
\hline Chap 6 laboratory & $\mathrm{SpO} 2$ & Percutaneous oxygen saturation & 30 & 1 & 30 \\
\hline Chap 7 image diagnosis & x-ray & Chest simple film (once) & 159 & 1 & 159 \\
\hline Chap 8 injection & Injection & Subcutaneous injection $500 \mathrm{ml}$ or less (for outpatient) & 18 & 1 & 18 \\
\hline Chap 8 injection & Injection & Intravenous drip (for outpatient) & 47 & 1 & 47 \\
\hline Chap 8 injection & Drug & See Appendix $2^{* *}$ & 120 & 1 & 120 \\
\hline Chap 8 others & NIPPV therapy & Nasal-intermittent Positive Pressure Ventilation & 65 & 1 & 65 \\
\hline Chap 9 others & Oxygen (addition) & $\begin{array}{l}\text { Oxygen: in case that } 11 / \mathrm{min} \text { perform for } 30 \mathrm{~min} \text {, Small } \\
\text { bombe is } ¥ 2.25 / 1, ¥ 67.5 \times \text { coefficient } 1.3=¥ 87.7 \Rightarrow 9 \\
\text { points }\end{array}$ & 9 & 1 & 9 \\
\hline & & & \multicolumn{2}{|c|}{ Cost per visit } & 13910 \\
\hline
\end{tabular}

Assumption to calculate the cost, (1) use NHIP revised in 2006, (2) assume that a patient visits a medical institution with 200 beds due to moderate attack at 22:00, (3) initial visit.

* Appendix 1.

\begin{tabular}{c|c|c|c|c|c|c}
\hline \hline Name & NHIP & Dosage & Unit & Cost & \multicolumn{2}{|c}{ Point } \\
\hline Atrovent aerosol & 1021 & 1 & Bottle & 1021 & $\Rightarrow$ & 102 \\
\hline \multicolumn{2}{|r|}{} & & Total & 1021 & Total & 102 \\
\hline
\end{tabular}

** Appendix 2.

\begin{tabular}{l|r|c|c|c|c|c}
\hline \multicolumn{1}{c|}{ Name } & NHIP & Dosage & Unit & Cost & \multicolumn{2}{c}{ Point } \\
\hline Epinephrine (subcutaneous injection) & 97 & 1 & Vial & 97 & $\Rightarrow$ & 10 \\
\hline Aminophyllin (intravenous drip) & 226 & 1 & Vial & 226 & $\Rightarrow$ & 23 \\
\hline Solu-Cortef 100 mg & 369 & 1 & Vial & 369 & $\Rightarrow$ & 37 \\
\hline Solita T3G & 500 & 1 & Bag & 500 & $\Rightarrow$ & 50 \\
\hline
\end{tabular}


換えることで試算した。また患者は，医療機関にお ける標榜時間外の夜間 10 時に受診したと仮定した (Table 3)。なお，SFCなどの喘息治療薬の費用は 含めていない.

予定外受診費用については，救急外来受診と同様 の初期及び追加治療レジメンを仮定し，それを診療 報酬点数で置き換えることで試算した。また患者 は，医療機関に標榜時間内に受診し，救急外来で行 われる検査, 画像診断, 及び処置は行わないと仮定 した（Table 4)。なお，SFCなどの喘息治療薬の費 用は含めていない。
以上の費用パラメーターを使用して，それぞれの 健康状態において消費する資源を仮定した（Table 5). なお，モデルは 1 週間の健康状態を推移するよ うに設計されているため，費用も 1 週間当たりの費 用で表示してある.

(1) Total control：主の喘息治療薬（SFC あるい は FP）費用のみ

(2) Well control：主の喘息治療薬（SFC あるい はFP）と併用薬剤の費用

(3) 要入院加療：入院費用

(4) 要予定外受診 : 予定外受診費用

Table 4. Regimen for Estimate of Unscheduled Visit

\begin{tabular}{|c|c|c|c|c|c|}
\hline Item 1 & Category & Condition & Point & Freq & Total \\
\hline Chap 1 visit fee & Follow-up visit fee & Once & 70 & 1 & 70 \\
\hline Chap 1 instruction fee & Drug information & Once a month for outpatient & 10 & 1 & 10 \\
\hline Chap 1 instruction fee & Asthma instruction & Once a month & 25 & 1 & 25 \\
\hline Chap 5 medication & Prescription filled & A medicine for external application (per prescription) & 6 & 1 & 6 \\
\hline Chap 5 medication & Prescription & Per prescription & 42 & 1 & 42 \\
\hline Chap 5 medication & Drug & See Appendix $1^{*}$ & 102 & 1 & 102 \\
\hline Chap 5 medication & Prescription slip & Prescription slip & 68 & 1 & 68 \\
\hline Chap 5 medication & Prescription skill & Prescription skill & 8 & 1 & 8 \\
\hline Chap 8 injection & Injection & Subcutaneous injection (for outpatient) & 18 & 1 & 18 \\
\hline Chap 8 injection & Injection & Intravenous drip (for outpatient) & 47 & 1 & 47 \\
\hline Chap 8 injection & Drug & See Appendix $2^{* *}$ & 120 & 1 & 120 \\
\hline & & & \multicolumn{2}{|c|}{ Cost per visit } & 5160 \\
\hline
\end{tabular}

Assumption to calculate the cost, (1) use NHIP revised in 2006, (2) assume that a patient visits a medical institution with 200 beds due to moderate attack at daytime, (3) follow-up visit.

* Appendix 1.

\begin{tabular}{|c|c|c|c|c|c|c|}
\hline Name & NHIP & Dosage & Unit & Cost & \multicolumn{2}{|c|}{ Point } \\
\hline Atrovent aerosol & 1021 & 1 & Bottle & 1021 & $\Rightarrow$ & 102 \\
\hline & & & Total & 1021 & Total & 102 \\
\hline
\end{tabular}

** Appendix 2.

\begin{tabular}{l|r|c|c|c|c|c}
\hline \multicolumn{1}{c|}{ Name } & NHIP & Dosage & Unit & Cost & \multicolumn{2}{c}{ Point } \\
\hline Epinephrine (subcutaneous injection) & 97 & 1 & Vial & 97 & $\Rightarrow$ & 10 \\
\hline Aminophyllin (intravenous drip) & 226 & 1 & Vial & 226 & $\Rightarrow$ & 23 \\
\hline Solu-Cortef 100 mg & 369 & 1 & Vial & 369 & $\Rightarrow$ & 37 \\
\hline Solita T3G & 500 & 1 & Bag & 500 & $\Rightarrow$ & 50 \\
\hline
\end{tabular}

NHIP; national health insurance price. 
Table 5. Resource Use and Costs Associated with the Model Health States

\begin{tabular}{l|l|c|c}
\hline \hline \multirow{2}{*}{ Health state } & \multicolumn{1}{c|}{ Resource costed } & \multicolumn{2}{c}{ Weekly cost (JPY) per patient } \\
\cline { 2 - 4 } & & SFC group & FP group \\
\hline Totally controlled & The cost of SFC or FP & $1533(50 / 100 \mu \mathrm{g}$ diskus) & $553(100 \mu \mathrm{g}$ diskus) \\
\hline Well controlled & The costs of SFC or FP and co-medication & $1533+1954$ & $553+1954$ \\
\hline Hospital-managed exacerbation & Hospitalisation cost & 268450 & 268450 \\
\hline Primary-managed exacerbation & Unscheduled visit cost & 5160 & 5160 \\
\hline Treatment failure* & Hospitalisation and emergency room cost & $268450+13910$ & $268450+13910$ \\
\hline
\end{tabular}

* For treatment failure state, it was assumed that resource costed at initial five cycles only and no resource consumed at remaining cycles due to asthma death. SFC; salmeterol/fluticasion combination, FP; fluticasone propionate.

（5) 不成功：入院及び救急外来受診費用

なお，Total 及び Well controlにおいては，外来 受診費用が薬剤費用よりも分析に与える影響は少な $<, 1$ 週間当たりに換算できる平均費用のデータも 入手できなかったため, 不確実性を増大させる対応 は避ける必要があると考え, 分析に含めなかった.

また, 不成功の場合, Price らは薬剂費用や入院 費用などを確率的に割り当てたと説明しているが, 日本の喘息治療の実態を考慮して, 不成功の状態に 移行した初回のみ救急外来を受診し, 観察期間中は 入院加療を継続すると仮定した.

\section{4. 基本ケース分析 上述の費用パラメーター} や 1 週間毎の移行確率をモデルに組み込み, 12 週 間観察における期待効果及び期待費用を計算した。 期待効果（主要評価指標として）は，12 週間のう ち total control 状態にある週の割合（患者一人当た り）で示した. FP 群（f）に対する SFC 群（s）の 経済評価を費用効果分析により行った。その際,

Eq. (1)から，FP 群に対する SFC 群の増分費用効果 比（incremental cost-effectiveness ratio: ICER）を計 算した.

$$
\begin{aligned}
& I C E R=\frac{C_{s}-C_{f}}{E_{s}-E_{f}} \\
& C: \text { 費用, } E: \text { 効果 } \\
& s: \text { SFC 群, } f: \text { FP 群 }
\end{aligned}
$$

また, 副次的評価指標として, 期待入院率及び期 待不成功率を計算した.

本分析は，EBM における意思決定のための判断 材料を提供するため，労働損失などの間接費用は考 慮せず直接費用のみを分析に組み込む医療費支払い 者（保険者）の立場で行った.
5. 感度分析（sensitivity analysis） Markov model による費用効果分析では多くの仮定条件を設 定したため, 基本ケース分析結果には不確実な要素 が含まれている．上述の費用パラメーターや移行確 率の中で，基本ケース分析の結果に影響を及ぼすと 考えられる因子を特定するために，トルネード分析 (1 変数が基本ケース分析に与える影響因子を画像 として示す手法）を試みた。 そして，トルネード分 析の結果から基本ケース分析に影響を与えると考え られる因子 1 つあるいは複数を変化させる感度分析 を試み, 頑健性 (robustness：分析結果の確からし さ）を検討した。なお，トルネード分析の結果は SFC 群の期待費用で示した.

さらに, あらゆる変数を包括的に捉え, 複数ある 不確実性な変数を同時に変化させることができ，使 用者の意思決定の判断材料として最も有効である統 計学手法, Monte Carlo 法（コンピューターによる 10000 回の自動ランダムサンプリング）による確率 論的感度分析 (Probabilistic sensitivity analysis) を 実施した. ${ }^{18)}$ なお，移行確率については，Eq. (2)に より標準誤差（S.E.）を計算し，基本ケースの移行 確率を平均とする確率分布（正規分布と仮定）とし てモデルに組み込んだ.

$$
\text { 標準誤差 S.E. }=\sqrt{\mathrm{p}(1-\mathrm{p}) / n}
$$

6. 分析ソフト 本分析では, 決断分析プログ ラム TreeAge Pro 2006 (TreeAge Software Inc., Willianstomn, MA）を使用した.

$$
\text { 結果 }
$$

\section{1. 費用効果分析（cost-effectiveness analysis）}

SFC 群及び FP 群における期待効果（主要及び副 
Table 6. Base Case Analysis on Cost-effectiveness of SFC vs. FP

\begin{tabular}{c|c|c|c|c|c}
\hline \hline \multicolumn{2}{c|}{ Expected cost (JPY) } & SFC & FP & Diff & ICER \\
\hline \multirow{2}{*}{$\begin{array}{c}\text { Expected } \\
\text { effectiveness }\end{array}$} & \% Totally controlled weeks & 160702 & 227820 & $\begin{array}{c}67118 \downarrow \\
(29.8 \% \downarrow)\end{array}$ & \multirow{2}{*}{ Dominant* } \\
\cline { 2 - 5 } & \% Hospitalisation rate & 1.0 & 2.0 & $\begin{array}{c}15.5 \% \\
(1.85 \mathrm{wks})\end{array}$ & $\begin{array}{c}1.0 \downarrow \\
(50.0 \% \downarrow)\end{array}$ \\
\cline { 2 - 5 } & \% Proportion of treatment failure & 7.4 & 14.0 & $\begin{array}{c}6.6 \downarrow \\
(47.1 \% \downarrow)\end{array}$ \\
\hline
\end{tabular}

ICER; incremental cost-effectiveness ratio, SFC; salmeterol/fluticasone combination, FP; fluticasone propionate. * Situation that SFC is more effective and less costly than FP.

次的評価指標について）及び期待費用をそれぞれ計 算し，費用対効果を検討した（Table 6).

\section{1-1. SFC 群における期待值 Markov model} によるシミュレーションの結果，SFC 群における 期待効果については，12 週間のうち total control である週の割合は $65.0 \%$ ，期待入院率は $1.0 \%$ ，及 び期待治療不成功率は 7.4\%であった。また，期待 費用は 160702 円（基本値）であった。

\section{1-2. FP 群における期待值 Markov model に} よるシミュレーションの結果，FP 群における期待 効果については，12 週間のうち total control であ る週の割合は $49.5 \%$, 期待入院率は $2.0 \%$, 及び期 待治療不成功率は $14.0 \%$ であった。また，期待費 用は 227820 円（基本值）であった.

\section{1-3. 基本ケース分析 $\mathrm{SFC}$ 群及び $\mathrm{FP}$ 群にお} ける期待効果（主要評価指標について）及び期待費 用から, FP 群に対する SFC 群の増分効果は 15.5 \%（1.85 週増）で，増分費用は一67 188 円（29.5\% 減）であった。そのため，ICER は計算せず，増分 効果及び増分費用のみを表示した。

\section{2. 感度分析 (sensitivity analysis)}

2-1. トルネード分析による影響因子の特定 下 記の因子を変化させた場合のトルネード分析（tornado diagram）を試みた結果，Total control から 要入院加療へと Total control から要予定外受診へ の移行確率が基本ケース分析結果に影響を与えると 推測された (Fig. 2).

1) Total control から要予定外受診の移行確率 を S.E. の範囲で変化させたところ，SFC 群 の期待費用は約 85000 円から 228000 円の 範囲で変化した。
2) Total control から要入院加療の移行確率を S.E.（なお，低值は一0.001 であったため， 0 と仮定した）の範囲で変化させたところ, SFC 群の期待費用は約 131000 円から 180000 円の範囲で変化した。

3）予定外受診費用を $\pm 25 \%$ で変化させたところ, $\mathrm{SFC}$ 群の期待費用は約 160000 円から 161000 円の範囲で変化した.

4）入院費用を $\pm 25 \%$ の範囲で変化させたところ, SFC 群の期待費用は基本值（160 702 円）と ほとんど変わらなかった。

5）救急外来受診費用を $\pm 25 \%$ の範囲で変化させ たところ，SFC 群の期待費用は基本值 （160702 円）とほとんど変わらなかった.

6）併用薬剤費用を 631-4 114 円（すなわち，95 \% CI）の範囲で変化させたところ，SFC 群 の期待費用は基本值（160702 円）とほとん ど変わらなかった。

2-2. 二元感度分析 (two-way multivariate sensitivity analysis）による基本ケース分析の頑健性の検 討 トルネード分析で特定した Total control か ら要入院加療へ，及び Total control から要予定外 受診への移行確率について，二元感度分析（上記の 範囲で同時に変化，なお「要予定外受診への移行確 率」は 0.008 とした）を実施したところ，それぞれ の移行確率が $0 \%$ 及び $0.35 \%$ のとき SFC 群の増分 費用は約 4000 円，増分効果が 1.70 週であった が，基本ケース分析結果の頑健性が示された。

2-3. 確率論的感度分析による統計学的検討

Monte Carlo 法による 10000 回のランダムサン プリングを行い, FP 群に対する SFC 群の増分効果 


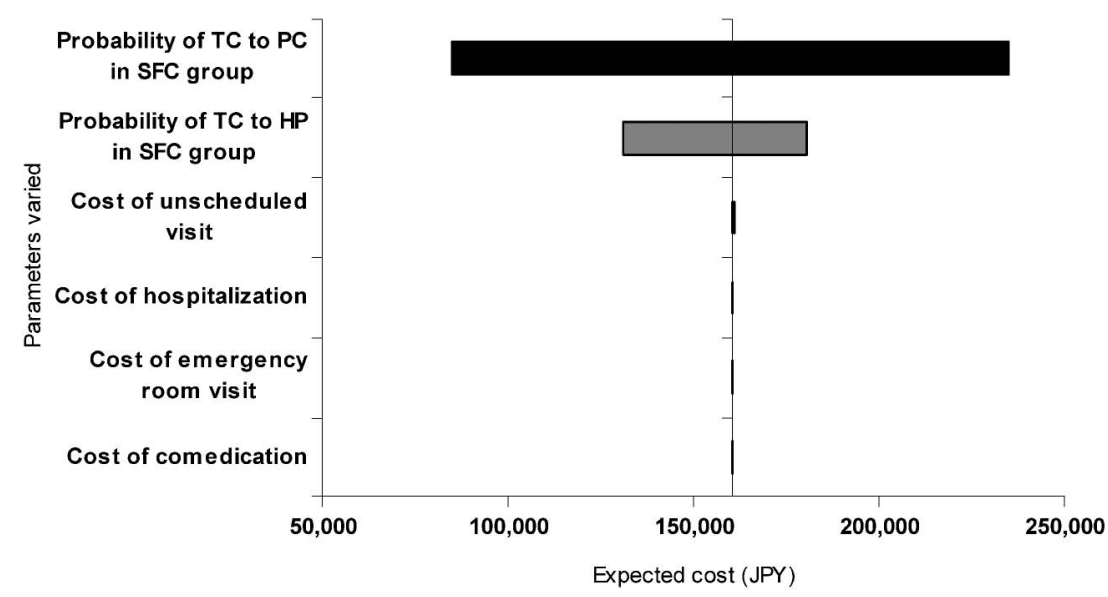

Fig. 2. Tornado Diagram for Identification of Parameters Affecting the Base Case in SFC Group $\mathrm{SFC}$; salmterol/fluticasone combination, TC; total control HP; hospital-managed exacerbation, PC; primary care managed exacerbation.

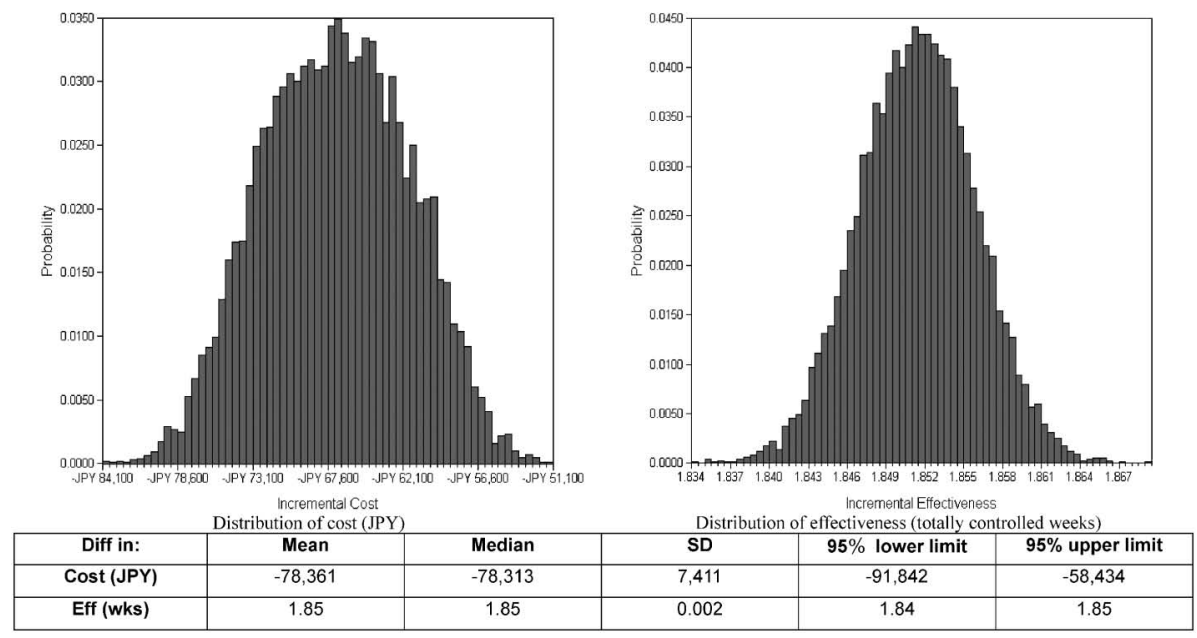

Fig. 3. Distribution of Cost and Effectiveness on SFC vs. FP Using Statistical Approach by 10 000-time Random Sampling $\mathrm{SFC}$; salmeterol/fluticasone combination, FP; fluticasone propionate.

及び増分費用の度数分布をプロットした。増分効果 では $95 \% \mathrm{CI}$ が 0 を挟んでいないことから，SFC 群 は FP 群が優れた効果を持っており，増分費用でも 95\% CI が 0 を挟んでいないことから SFC 群が FP 群に対して費用削減的である結果に変わりはなく, 基本ケース分析結果の頑健性が示唆された（Fig. 3)。さらに，横軸を増分費用，縦軸を増分効果とし た費用対効果図（Fig. 4 を参照）上に二次元的にプ ロットしたところ，95\% CI はすべて増分効果でか つ費用節減的であるという相対的優位な位置に集中 していた（Fig. 5).

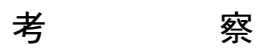

今回，筆者らは日本において SFC の費用対効果
を検討するため, Step 3 以上の喘息患者における FP に対する費用効果分析を試みた。その結果, SFC 群では FP 群に対して観察期間中に total control の状態を長く維持することができ，かつ医療費 の節減効果がみられ，FP 群と比べ費用対効果に優 れていた。 そのため，本分析では ICER は計算しな かった，その理由としては，増分費用と増分効果は Fig. 4 に示すとおり比較対照を $\mathrm{x}$ 軸， $\mathrm{y}$ 軸の交点と した 4 領域（quadrant）で示され（費用対効果平面 図：cost-effectiveness plane), 効果と費用いずれか のみで負の整数を取ることで費用対効果の判断が明 白なためである．例えば，効果が負の整数の場合は 比較対照より費用対効果が劣つていること（dominated）を示し，逆に費用のみが負の整数の場合は 


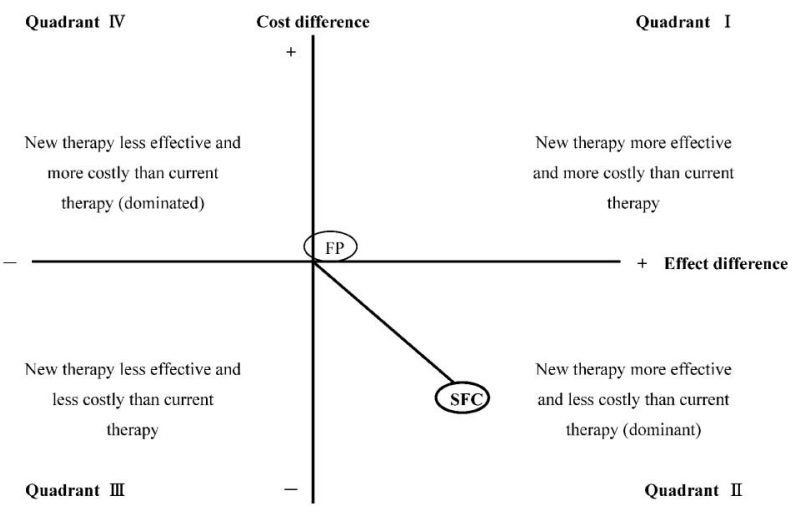

Fig. 4. Definition of Cost-effectiveness and the Cost-effectiveness Plane

In the diagram the horizontal axis represents the effect difference between SFC and FP for example, and the vertical axis represents the cost difference. The alternative (FP) could be the status quo or a competing programme. If point is in quadrants II or IV the choice between the programmes is clear. In quadrant II SFC is both more effective and less costly than FP. That is, it dominates FP. In quadrant IV the opposite is true. In quadrants I and III the choice depends upon the maximum cost-effectiveness ratio one is willing to accept (willingness to pay; WTP).27)

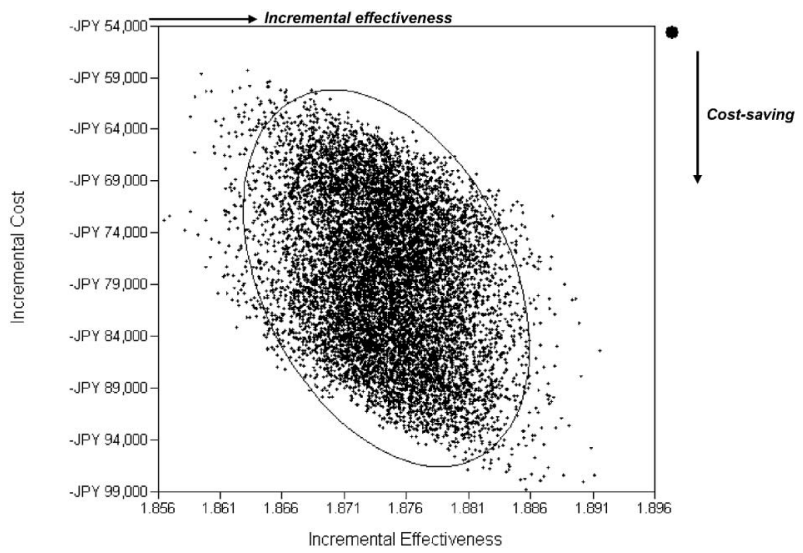

Fig. 5. Probabilistic Sensitivity Analysis on SFC vs. FP Using Statistical Approach by 10 000-time Random Sampling

Dots indicate cost-effectiveness for individual. An ellipse indicates $95 \%$ confidence surface. SFC; salmeterol/fluticasone, FP; fluticasone propionat.

比較対照より高い効果と費用節減効果 (dominant) を持つことを示す.

また, 確率論的感度分析の結果から SFC 群は FP 群に対して統計学的有意に費用対効果に優れている という頑健性が得られた。なお，宮川ら ${ }^{19)}$ は，ICS にSLM を併用することによる費用節減効果を小規 模な遡及的調査で報告しており，喘息治療に対して 日本でも臨床的かつ経済的に良好な影響を与えると 結論づけていることからも，本研究結果は支持され るものであると考える.

本分析は，Priceらが報告した Markov model
に，日本独自の費用パラメーターを組み込んで， SFC 群の FP 群に対する費用対効果を検討した．研 究に当たり, 海外の先行研究について精查を行っ た. 先行研究に関しては, 次のような特徵がみられ た。

1）臨床試験に付随した費用効果分析（costeffectiveness analysis alongside clinical trial) である.

2）効果指標は，主に，Symptom-free/episodefree days や $\mathrm{FEV}_{1}$ と言つた中間的な指標と, AQLQ (Asthma Quality of Life Questionnaire）という QOL 指標を用いている.

3）時間地平が主に 1 年末満の短期間であり, 1 年以上の長期間における費用効用分析 （CUA）の報告がわずかである.

これらのことから，日本における研究も短期間で の技術の評価と長期間での評価が必要ではないかと 考えられた。海外の先行研究に関する総括を見て も，日本では経済評価に利用可能な効果指標を持つ 臨床研究はなく，代替としてモデルを用いた分析が 妥当と考えた。

数ある先行研究の中で, SFC の評価を CUA で検 討した報告が 2 報ある。 Briggs ら ${ }^{20)}$ は欧州で実施さ れた大規模臨床試験 GOAL（The Gaining Optimal Asthma controL) study の生データに遡って経済評 価に発展させている，GOAL studyでは，3つの SFC あるいは FP による治療計画について 1 年間に おける有効性と安全性を検討しているが，いずれの 治療計画も ICER（cost per QALY gained）が英国 NICE (National Institute for Health and Clinical Excellence）の定める意思決定の閾値より低かったた め，費用対効果的と結論づけている。 しかし，この 研究では効用值を GOAL study の中で直接測定し ておらず，臨床指標に効用值を割り当てて間接的に QALY を計算している点が問題である。また， Doull ら 21 )の報告では，FP に対する SFC (低用量, 中用量）の評価は, dominant-£6852/QALY gained と SFC 群は費用対効果的であると結論づけている が，Briggs ら20) と同様，間接的に QALY の計算を している。このように，海外においても長期にわた る経済評価は十分ではなく，今後日本で進めていく 上でも検討課題である.

仮に先の基本ケース分析結果を外捜して年間の医 
療費に与える影響を検討すると，医療費全体に与え る影響は少ないが，19 から 38 億円の医療費削減が 期待される。なお，医療財政への影響の推計方法を 下記に示す.

厚生労働省の平成 17 年患者調査 ${ }^{22}$ から, 成人 （統計上の問題から 15 歳以上とした）患者 64 万人 (a) を対象とした。さらに AIR-J200523) から Step 3 以上の割合を $27 \%(b)$ とした。 また，ICS の浸透率 を $20 \%(c)$ と仮定し，直接費用の差 $\Delta$ を 67188 円 (d) とした。そして，すべてのStep 3, 4 患者が SFC を使用した場合と, その半分の場合を想定し た場合の計算は次のとおりである.

・すべての Step 3-4 患者が SFC を使用した場合 年間医療費削減 $=a \times b \times c \times d=2322017200$ 円

-Step 3, 4 の半分の患者が使用した場合はその $1 / 2$ $=1161008600$ 円

上述のように SFC 導入による医療財政への影響 はわずかであるが，筆者らが別に報告したとおり ICS を使用していない患者に FP 導入することによ り半年間で約 155-310 億円の経済効果が期待さ れ, ${ }^{19)}$ また分析対象患者が Step 3, 4 に絞られてい るため, FP から SFCへの切り替えによる費用削減 幅がわずかになったのではないかと考える。しか し，本稿ではこれまで直接医療費のみに焦点を当て て議論しているが，喘息患者が急性増悪に起因して 就労につけず労働損失を被ることになると, Step 3 -4 の喘息患者にとって SFC によって得られる経済 効果は計り知れない.

本研究でモデルに組み込んだ変数は海外の臨床成 績を出所としているため，基本ケース分析や感度分 析結果の解釈に若干制約がある。例えば，臨床現場 への直接的な一般化（transferability）が難しく, いわゆる外的妥当性（すなわち，得られた統計学的 推論が，興味のある母集団にも一般化することが可 能かどうか）の問題が指摘されている. ${ }^{24)}$ 実際，喘 息治療では 12 週間だけで治療結果の評価を行うわ けではなく，長期間観察における臨床評価は必須で ある. 臨床試験のデザイン上の問題から両群間に差 が最も認められ易い短期間での観察が行われ，長期 間での観察では臨床効果について差が認められない

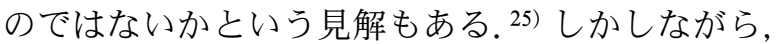
長期間観察において臨床効果の側面では同等であつ た場合，医療従事者や医療政策者などが治療選択を
意思決定するためにはどんな判断材料が必要であろ うか。幸い，経済学の領域では時間選好（time preference）という考え方があり，将来得られる便 益よりも現在得られる便益の方が好まれるという考 え方がある，すなわち，喘息治療の場合も SFCに よって早期に total control に達成することは，長時 間かけて total control に達する場合に比べてより短 期間に得られる医療費削減の方が重要で，それは治 療選択の意思決定上，十分に判断材料となると考え る.

\section{結論}

SFC は FP に対して費用対効果に優れている可能 性が示唆されたことから，喘息の治療と管理におい て SFC 使用は臨床的かつ経済的も意義がある治療 法であると考えられた。しかし，今後は本研究で使 用した Markov model を用いて長期間の費用対効果 を評価していく必要があると考える。

\section{REFERENCES}

1) Inagaki N., Allergology \& Immunology, 14, 658-674 (2007). (in Japanese)

2) Usmani O. S., Maneechotesuwan K., Ito M., Johnson M., Barnes P. J., Adcock I. M., Am. J. Respir. Crit. Care Med., 172, 704-712 (2005).

3) Jenkins C., Woolcock A. J., Saarelainen P., Lundback B., James M. H., Respir. Med., 94, 715-723 (2000).

4) Theophilus A., Moore A., Prime D., Rossomanno S., Whitcher B., Chrystyn H., Int. J. Pharm., 313, 14-22 (2006).

5) Nelson H. S., Busse W. W., Kerwin E., Church N., Emmett A., Rickard K., Knobil K., J. Allergy. Clin. Immunol., 106, 10881095 (2000).

6) Adachi M., Ohta K., Sano Y., Taniguchi H., Ishihara K., Aizawa H., Nakajima M., Allergology \& Immunology, 12, 922-935 (2005). (in Japanese)

7) Stoloff S. W., Stempel D. A., Meyer J., Stanford R. H., Carranza Rosenzweig J. R., J. Allergy Clin. Immunol., 113, 245-251 (2004).

8) Japanese Society of Allergology, "Japanese Guideline for the Diagnosis and Treatment of Allergic Diseases 2007," ed. by Nishima S., 
Kyowa Kikaku, Tokyo, 2007. (in Japanese)

9) Global Initiative for Asthma (GINA), "Global Strategy for Asthma Management and Prevention,": 〈http://www.ginasthma.org $\rangle$, cited 24 April, 2009.

10) US Department of Health and Human Services, "Expert Panel Report 3 (EPR3) : Guidelines for the Diagnosis and Management of Asthma, Full Report 2007,'’: 〈http://www. nhlbi.nih.gov / guidelines / asthma / asthgdln. htm $\rangle$, cited 24 April, 2009.

11) Petitti D. B., "Overview of the methods, Meta-Analysis, Decision Analysis and Costeffectiveness Analysis: Methods for Quantitative Synthesis in Medicine,", ed. by Petitti D. B., Oxford University Press, New York, 2000, pp. 13-32.

12) Statistics \& Information Department, Ministry's Secretariat, Ministry of Health, Labour and Welfare, "Survey of Medical Care Activities in Public Health Insurance 2006,'”: 〈http: //wwwdbtk.mhlw.go.jp/toukei/index.html $\rangle$, cited 24 April, 2009. (in Japanese)

13) Price M., Briggs A. H., Pharmacoeconomics, 23, 183-194 (2002).

14) Pharmaceuticals and Medical Devices Agency, “Approval Application forms of Adoair 100, 250, 500 Diskus (approved in April 2007), Chapter 2 of CTD summary,'’: 〈http://www. info.pmda.go.jp / shinyaku / g070403 / index. html? $\rangle$, cited 24 April, 2009. (in Japanese)

15) Kavuru M., Gross G., LaForce C., House K., Prillaman B., Baitinger L., Woodring A., Shah T., Melamed J., J. Allergy Clin. Immunol., 105, 1108-1116 (2000).

16) Miyamoto T., Morita H., Tamura G., Tohda Y., Arakawa I., Shiragami M., Allergy, 55, 542-553 (2006). (in Japanese)

17) Central Social Insurance Medical Council, Committee Material for DPC Evaluation,
"Average Duration of Hospitalization for Asthma Treatment in the 2005 Fiscal Year,'”: 〈http://www.mhlw.go.jp/shingi/2006/04/dl/ s0427-3d53.pdf $\rangle$, cited 24 April, 2009. (in Japanese)

18) Briggs A. H., "Handling Uncertainty in Economic Evaluation and Presenting the Results, Economic Evaluation in Health Care: Merging Theory with Practice,'” eds by Drummond M., McGuire A., Oxford University Press, New York, 2001, pp. 172-214.

19) Miyagawa T., Arakawa I., Shiragami M., Nishimura S., Yakugaku Zasshi, 126, 51-59 (2006).

20) Briggs A. H., Bousquet J., Wallace M. V., $A l$ lergy, 61, 531-536 (2006).

21) Doull I., Price D., Thomas M., Hawkins N., Stamuli E., Tabberer M., Gosden T., Rudge H., Curr. Med. Res. Opin., 23, 1147-1159 (2007).

22) Statistics \& Information Department, Ministry's Secretariat, Ministry of Health, Labour and Welfare, 'Patient Survey 2005,'” 〈http: //wwwdbtk.mhlw.go.jp/toukei/index.html $\rangle$, cited 24 April, 2009. (in Japanese)

23) Adachi M., Ohta K., Morikawa A., Nishima S., Tokunaga S., DiSanostefano R. L., $A l$ lergy, 57, 107-120 (2007). (in Japanese)

24) Drummond M., Pang F., "Transferability of Economic Evaluation Results, Economic Evaluation in Health Care: Merging Theory with Practice," eds. by Drummond M., McGuire A., Oxford University Press, New York, 2001, pp. 256-276.

25) Bjermer L., Bisgaard H., Bousquet J., Fabbri L. M., Greening A. P., Haahtela S. T., Holgate S. T., Picado C., Menten J., Dass S. B., Leff J. A., Polos P. G., BMJ, 327, 891-895 (2003). 